ISSN 2616-7573 (Print), ISSN 2617-1104 (Online)

UDC: $37.014: 351.851$

JEL Classification: J22, J25, P36, P43

Received: 14/09/2019

\author{
Alina Hrushyna \\ Senior Lecturer, $\mathrm{PhD}$, Kyiv National University of Culture and Arts, \\ 36, Y. Konovalets st., 01601 Kyiv, Ukraine; e-mail: \\ alinahrushyna@gmail.com; tel.: +380932105575
}

\title{
The State Policy Formation of Educational Management
}

\begin{abstract}
Introduction. Nowadays Ukraine, along with other countries of the world, defines education as a strategic and one of the most important goals of the state. Thus, a young person who has graduated is considered more competitive in the labor market, since he has the complex of skills and knowledge that shape his potential. Such a potential, first of all, should be the basis for a significant improvement in the economic and social situation both individually and society as a whole. In the framework of providing quantitative and qualitative characteristics of human potential, the relevance of the study of modern problems in the management of the educational system is increasing. Purpose and methods. The purpose of the paper is to highlight the main steps and actions of the state in shaping the policy of managing the educational process in Ukraine. In this study we used empirical and systematic approaches, according to which the processes of formation of the policy of management of educational process, which are being used today, are analyzed in the interconnection and development. Economic and statistical methods are also used. Results. The modern system of educational process management is investigated, the level of efficiency of the state reform of decentralization is determined in the educational sector. The problem of the catastrophic isolation of the education system from the labor market is revealed. The expediency of the use of tools for the implementation of the dual education system for the solution of this problem is substantiated. Conclusions and discussion. The scientific novelty of the obtained results is to distinguish the main directions of the formation of the policy of public administration in the educational process. The use of the proposed approaches and practical recommendations will improve the quality of education and reduce the level of youth unemployment.
\end{abstract}

Keywords: education, youth, management system, unemployment, state. 


\section{Introduction}

The problem formulation. Priority directions of further development chosen by Ukraine, in particular the process of European integration, cause today's transformational changes in absolutely all sectors of the functioning of the state. Global problems of economic, political and socio-cultural nature make the education sector strategically important for the sustainable development of the country. Today, despite the high position of the state in the world ranking in terms of population coverage, there are problems of a large-scale and promising nature. These include the accessibility of the population to the Internet resource, the level of quality of education of both general and higher education institutions. However, the main problem is the inconsistency of the modern education system with the latest requirements of the labor market and the complexity of the transformation process of a huge unit of the education system. Such a mismatch in the education system is the root cause of youth unemployment, migration of the country's potential and the outflow of the younger generation abroad, which together reduce the economic development rate of the country. Therefore, the development of adequate market mechanisms for the implementation of education policy, which aims to ensure significant changes in the economic and social environment, both individually and society as a whole, becomes a priority of the state. In such circumstances, the urgent question is to formulate an effective policy for managing the educational process in the direction of approaching market requirements, taking into account the requirements and conditions of European integration concepts.

State study of the problem. The issues of education reform at the state level, building management mechanism engaged in the educational process are known as foreign scientists A. Alton-Lee (2006), M. Petrilli ( 2018), I. Baker (Baker et al., 1994), M. Iarychev (2016). The researchers examined the experience of countries around the world and identified a number of major factors that influence the effectiveness of education reform. World-wide and European organizations have developed modern methods of assessing the level of education of the population, on the basis of which are ranked the countries of the world by indexes of coverage of the population by education and the ability to retain talents (human and scientific potential). These indices allow identifying problem areas in the educational process management system. The problems of educational reform, in particular, the study of decentralization and its impact on the results of the educational process were investigated by such national scientists as V. Kremin' (Kremin' et al., 2013), V. Meleshko (2018). Works by S. Zhabin, O. Kaz'mina (2017), S. Kucherenko (2018), L. Tytarenko, S. Maliuha (2014). Their work focuses on youth unemployment as a result of an inefficient policy of managing the education sector, and the lack of education to meet labor market requirements. Problems of formation of policy 
of management of educational process, its improvement, substantiation of paradigm of management-education were considered by domestic scientists L. Bielova (2018), Ya. Martynyshyn (Martynyshyn et al., 2017), V. Maslov (Maslov et al., 2012), T. Shtyfurko (2018) and others.

Unresolved issues. However, current conditions require a revision of the basic principles of science and adapt them to the present. The education reform, in the absence of a mechanism for managing the educational process, leads to a decrease in the quality of education, which is the main cause of youth unemployment, and along with it justified migration of the country's potential. However, the domestic education system cannot be transformed by foreign models, taking into account existing problems of socio-economic nature. Therefore, the process of forming an effective policy of managing the educational process in the direction of ensuring the conformity of education to the requirements of the labor market, the implementation of a strategic management mechanism using appropriate tools to ensure the sustainable development of the country remains insufficiently researched.

\section{Purpose and research methods}

The purpose of the article is to highlight the main measures and actions of the state in the direction of forming an effective policy of management of the educational process in Ukraine, which will allow to form an effective mechanism for improving the quality of education and reducing youth unemployment.

The methodological basis of the study. According to the purpose of the article, a systematic approach to the study of the real situation of socioeconomic processes in Ukraine, in particular such as decentralization of the educational process, has been used for the analysis.

In order to evaluate the scope and direction of change in the activity of educational institutions at all levels, an empirical analysis of the achievements of leading scientists who researched foreign experience of reforming the education system has been conducted. As a result, the main problems of transformation processes in Ukraine are identified and mass youth unemployment and migration processes of the country's scientific potential.

The analysis of the causes and motives of the decline in the quality of education as a factor of youth unemployment and migration is based on a secondary analysis of available information on labor migration from Ukraine, obtained from sample observations during 2013-2018. The main producers of information are the State Statistics Service of Ukraine, the National Academy of Sciences of Ukraine and the rating systems of the World Organizations. The characterization of the consequences of the mass depletion of human resources of Ukrainians abroad as a result of the mismatch of the level of education with the current market conditions was made on the basis of the analysis of the situation on the labor market of Ukraine. 
Research methods. Methods used general scientific knowledge of the socio-economic phenomena and processes, such as: abstract logic and method of analysis are in the study of approaches to the policy of management of the educational sector; systematic approach in generalizing the complex of actions of state authorities and educational institutions in the direction of improving the quality of education and reducing the level of youth unemployment. The economic-statistical method was used in the collection, systematization and processing of information, as well as the assessment of the actual status of Ukraine in the world rating system. Using the methods of comparative analysis and diagnostics the peculiarities and tendencies of development of the educational sector are revealed, which is reflected in the form of tables and graphs. It has been used functional and system-structural approach in the classification of the strategic objectives of the education system.

Research information base. The obtained results are based on the provisions of management theories, scientific works of leading domestic and foreign scientists on management in the educational sector, as well as normativelegislative acts on reforming Ukraine's education and sustainable development strategies, statistics of the State Statistics Service of Ukraine on the activities of general educational institutions of education, financing of the educational sector, data of world organizations on ratings and Ukraine's position in them and the results of own research.

\section{Research results}

Nowadays, in the context of constant changes in Ukraine, education is not only a strategic resource of the state, but also a major imperative for development. The functioning of the economy of the country as a whole system must foresee, first of all, the development of the population, the formation of a conscious and highly intellectual society. These changes affect higher education institutions as a key factor in ensuring the development of the society's intellectual potential.

In today's conditions of economy development in Ukraine, the concepts "market" and "education" become interdependent. Education, which in the context of a closed society has traditionally been considered a public good, and it is turning into a service, and its institutions take on the role of full participants in the market environment. In this environment, one of the key elements is commercial success aimed at increasing the cultural and educational level of the population.

In such circumstances, any educational entity combines a set of material as well as intangible resources (financial, human, informational, intellectual, material, technical), which makes it possible to ensure the desired quality of the educational process. 
Thus, the first priority of the state, which would be the direction of development and integration is chosen, is to educate people in an innovative mindset and culture. Therefore, special attention from the state should be paid to the development and implementation of state programs, concepts for the development of cultural and artistic and educational institutions, which will positively influence their further development, promote the education of the society and enrich the cultural environment of the nation (Martynyshyn et al., 2017).

This function rests primarily on educational, cultural and artistic institutions that, in close symbiosis, have the effect of growing the cultural, educated and intellectual community (Martynyshyn et al., 2017).

Today, under the influence of European integration processes, an important issue is the change in the number of such educational institutions, in particular general secondary education, which is directly influenced by the decentralization reform.

In the Table 1 figures show a decrease in the number of general education institutions despite the increase in the number of students. This phenomenon is justified by the impact of the decentralization process and the creation of support schools. However, as testimonials and interviews of many school principals testify, the problem of creating supportive educational institutions is by no means legal, but rather public. It is the teachers against such cuts and transformations as they perceive it as a threat to lose their jobs.

However, the data in the table 1 indicates the opposite effect. In the 2017-2018 academic year, the number of general education institutions decreased compared to the 2016-2017 academic year, but the number of students and even teachers themselves increased.

For example, the institutions themselves are down 700 units, but the number of students is 76 thousand more than the number of teachers is 2 thousand.

Vira Meleshko (2018) states in her work that "the transition to decentralized management in basic educational institutions is connected with the fear of some managers to reduce or weaken control over the dynamics of the institution's development, the other is to lose the authority of the leader, to reduce the influence on subordinates, etc." (p. 31).

Thus, we can conclude that the process of decentralization in the education sector has a positive result, despite the resistance to the system of stakeholders in the education sector.

Valentyn Maslov (2012) also notes in his work the importance of the financial part of decentralization. Thus, reducing the number of general education institutions has led to the saving of the some financial resources, which are accumulated in the reference schools, which give somewhat more effective results. 
Table 1. Quantitative indicators of general education activities.

Eucational institutions of Ukraine

\begin{tabular}{|c|c|c|c|}
\hline $\begin{array}{c}\text { At the beginning } \\
\text { of the school year }\end{array}$ & Institutions & Pupils & Teachers \\
\hline $2013 / 14$ & 19.3 & 4204 & 508 \\
\hline $2014 / 15$ & 17.6 & 3757 & 454 \\
\hline $2015 / 16$ & 17.3 & 3783 & 444 \\
\hline $2016 / 17$ & 16.9 & 3846 & 438 \\
\hline $2017 / 18$ & 16.2 & 3922 & 440 \\
\hline
\end{tabular}

Source: developed on the basis of (State Statistics Service of Ukraine, 2019)

The effectiveness of decentralized management of general education institutions is also evidenced by education expenditures. For example, in 2018 , for the quarter ( 9 months), the financing plan for UAH 254.1 million was fulfilled, while in 2016 only UAH 196.9 million was financed for the whole year, in 2017 the amount was 284 million UAH (State Statistics Service of Ukraine, 2019).

So, if we are talking about reform processes in the country, it is necessary to study the main priorities of the country's policy and determine the place of education in the general road map of its development.

Sustainable Development Strategy "Ukraine 2020" aims at "introduction of European standards of living in Ukraine and Ukraine's leading position in the world" (Cabinet of Ministers of Ukraine, 2015). However, with regard to education, it was briefly referred to in the overall strategy as "education reform" in a particular vector of responsibility.

The National Strategy for the Education Development in Ukraine until 2021 defines the following losses in the process of reforming Ukrainian education as follows (Cabinet of Ministers of Ukraine, 2013):

- lack of a systematic science-based ideology of educational development, its situational politicization, weak influence on the educational and cultural level of society, which led to a significant weakening of the consolidating, modernizing mission of education;

- curtailing the network of preschools as a result of removing power from environmental issues;

- lack of a forecast of demographic situation and educational development needs in the regions;

- lack of legal framework for the status of land and buildings that made this educational unit unavailable to provide pre-school education, especially for older preschool children (Kucherenko, 2018).

At the same time, strategic indicators for the implementation of such a reform are chosen such as "75 percent of graduates of general educational 
institutions will have at least two foreign languages, which will be confirmed by international certificates" and "Ukraine will participate in the inter-national PISA education quality survey and enter the top 50 countries participating in such research" (Ministry of Education and Science of Ukraine, 2014).

As noted in previous papers (Hrushyna, 2018), methods of calculating such indicators have not been proposed, and state structures are not accountable for the status and results of achieving such indicators.

In its turn, the draft Sustainable Development Strategy of Ukraine for the period up to 2030 enhances the educational process only in the context of operational goals, point 4.2. - "Provide inclusive and equitable quality education and promote lifelong learning opportunities for all", which is a positive factor, of course, but does not solve the problem of skills development in sectors that develop and support the country's economy as a whole (UNDP Ukraine, 2017).

Thus, according to Table 2, we observe that the number of students in the 2017-2018 school year is about one and a half million people, while in the 2010-2011 school year -2.4 million.

Table 2. Quantitative Activity Indicators.

Higher educational institutions of Ukraine

\begin{tabular}{|l|c|c|c|c|c|}
\hline \multirow{2}{*}{ Indicator } & \multicolumn{5}{|c|}{ At the beginning of the year } \\
\cline { 2 - 6 } & $2013 / 14$ & $2014 / 15$ & $2015 / 16$ & $2016 / 17$ & $2017 / 18$ \\
\hline Institutions & 767 & 664 & 659 & 657 & 661 \\
\hline $\begin{array}{l}\text { Students: total } \\
\text { (thousand) }\end{array}$ & 1993 & 1689 & 1605 & 1587 & 1539 \\
\hline $\begin{array}{l}- \text { accepted for } \\
\text { training }\end{array}$ & 428 & 361 & 323 & 314 & 324 \\
\hline \multicolumn{1}{|c}{ - graduates } & 560 & 484 & 447 & 387 & 421 \\
\hline
\end{tabular}

Source: developed on the basis of (State Statistics Service of Ukraine, 2019)

The total reduction of the student contingent reached $37 \%$. A similar trend is observed in the decrease in the number of higher education institutions. In particular, their number decreased by $19 \%$ (in 2018 there were 661, and in $2010-813$ ).

As we can see in Figure 1, the interdependence of the change in the student contingent and the number of universities until the 2017-2018 academic year, when the number of educational institutions has increased despite the decrease in the volume of students, clearly show.

We have also compared the rate of change in the population of the country, which, in our opinion, should be taken into account in the formulation of policy and reform of the educational process at the national level. 
Because, the network of educational institutions should provide free access to education for citizens as envisaged by the Constitution of Ukraine. We bear in mind that the official growth of the population of 2017-2018 against the background of 2015-2016, to some extent justifies the slight increase in the number of educational institutions of both general education and universities in Ukraine.

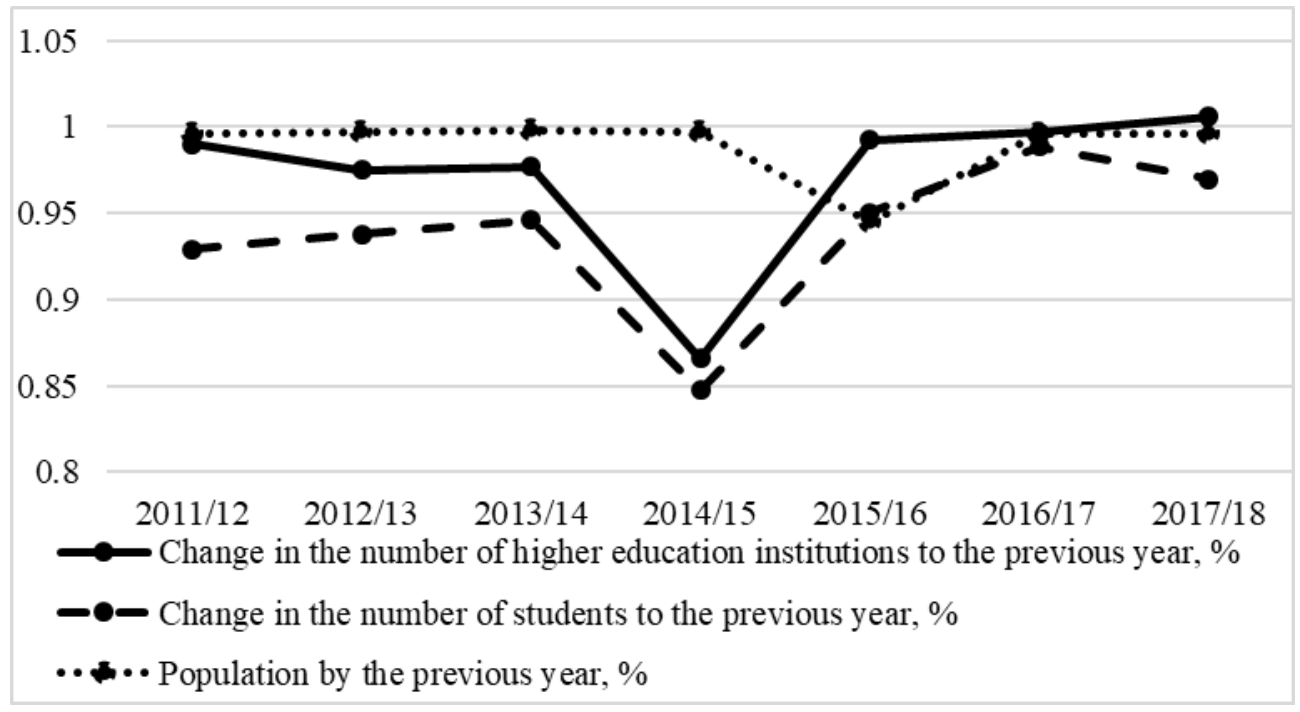

Figure 1. Dynamics of activity of higher educational institutions Source: own development

Despite decisive action in the area of education reform, Ukraine holds the position of a country with a rather mediocre level of human capital on the world stage. This fact is borne out by the UN Development Program Index, which calculates the Human Development Ratio and Global Human Capital Rating, prepared by the World Economic Forum.

In 2017, Ukraine ranked 88th out of 189 countries in the ranking, while in 2016 it ranked 84th (World Economic Forum, 2017).

At the same time, the Human Development Index (HDI), according to the methodology of the World Economic Forum, is the final indicator for assessing the long-term progress of human development in three main dimensions:

1) long and healthy life;

2) access to knowledge;

3) decent living standards (UNDP Ukraine, 2018).

An indicator of a long and healthy life is measured by average life expectancy. At the same time, "the level of knowledge is measured by the average number of years spent on adult education, that is, the average num- 
ber of years of life-long learning in people over 25 years of age; and access to learning and knowledge are expected years of learning for first-graders. The standard of living is measured by the Gross National Income (GNI) per capita in 2011 Permanent Purchasing Power (USD), converted by Purchasing Power Parity (PPP) ratios" (UNDP Ukraine, 2018).

According to the experts, the "high" position in the ratings was primarily due to the fact that the citizens of Ukraine have a sufficiently high level of literacy and education of the population. The "education" index of Ukraine's population appears to be ranked 5th in the world, although according to the global human capital rating, only 50th place out of 157 countries in the list, which is slightly above average.

World Economic Forum publishes "Global Competitiveness Index of the World Countries, which consists of more than 100 variables, grouped into 12 benchmarks such as: institutions, infrastructure, macroeconomic environment, health and elementary education, higher education and vocational training, labor market efficiency, technological readiness, innovation potential, etc.). They are integrated into 3 major sub index groups: basic requirements, performance enhancers and innovations, and enhancement factors" (Ekonomichnyi dyskusiinyi klub, 2017).

As you can see, the above index also takes into account the educational component, with both at the elementary school and higher education levels.

According to the data (World Economic Forum, 2018), Ukraine lost its position in 4 of the 12 main indicators. We suffered the biggest losses in the Labor Market Efficiency component is below 13 points, which we believe and it is directly related to the efficiency of the educational process. "The tendency to worsen this indicator was observed in last year's studies, and in the last year, we worsened its positions by 17 points" (Ekonomichnyi dyskusiinyi klub, 2017).

Thus, the methodology for calculating the labor market efficiency indicator takes into account such factors as "the country's ability to retain talent" and "the country's ability to attract talent". Taking into account the outflow of young people from Ukraine and the level of youth unemployment, the failure of the country by this rating becomes understandable.

According to research, youth is one of the most vulnerable categories of the population in the labor market. The high unemployment rate of the population aged 15-24 is due to the fact that a large part of young people at that age do not have the necessary professional skills and work experience that meet the requirements of employers.

In Ukraine, the share of economically inactive youth is predominant among young people aged 15-24 (almost $65.6 \%$ in 2017), as most young people in that age study. Almost $85 \%$ of the inactive population aged 15-24 were students and students (World Economic Forum, 2017). 
Today, a population structure has been formed, characterized by high proportions of older and low younger people. As of January 1, 2018, the number of people aged $0-15$ years was $16.3 \%$ of the total permanent population, aged 60 and over $-22.9 \%$, aged $16-59-60.8 \%$.

Age structure determines demographic burden: as of January 1, 2018, there were 269 people aged 0-15 years and 1,000 people aged 60 and over per 1,000 people aged 16-59 (State Statistics Service of Ukraine, 2019).

We observe not only the natural process of aging of the nation, but also the tendency to increase the level of youth unemployment, and as a consequence of its intensive migration.

The role of young people in today's post-industrial society is increasing as they become more dependent on innovation. The innovative character of modern social development makes the participation of young people in the functioning of the industrial and social spheres as full partners. It is the young minds who make the most of scientific discoveries, put forward many social and economic initiatives, develop a significant number of technical improvements, offer maximum "fresh" ideas. Thus, it is youth who act as a resource to create competitive advantage (Iarychev, 2016).

Lubov Tytarenko (2014) notes in his work that the imbalance in the labor market and it is also the reluctance of employers to hire young professionals due to their low level of practical training. In order to balance the labor market, it is necessary to enable future specialists to acquire both theoretical and practical skills in their chosen professional activity.

In order to identify problems that "young scientists face and what moods prevail in their environment, in 2015-2017, a survey was conducted at the institutions of the National Academy of Sciences of Ukraine, Kyiv National University Taras Shevchenko and Kyiv Polytechnic Institute" (Shtyfurko, 2018).

The results of the study are not representative of the country as a whole, but make it possible to understand what challenges and threats are facing the population of the country, which is its potential future.

According to a study conducted at the National Academy of Sciences of Ukraine in 2016, the following conclusions were made: $42.2 \%$ of young scientists stated their intentions to migrate. In 2017, there were $51.2 \%$ of them, $15.7 \%$ intended to leave Ukraine permanently, and $35.1 \%$ considered the prospect of employment with a further return (Zhabin \& Kaz'mina, 2017).

Therefore, it is quite logical that Ukraine also suffered significant losses when calculating the innovative component is minus 9 points; infrastructure is 3 points and the indicator that characterizes the level of higher education and training are 2 points.

Considering the components of the above indicators, it can be seen that education is an important factor in the development of the country both economically and socially, and therefore is a strategic resource of the country. 
Thus, we can conclude that one of the most serious problems of Ukrainian higher education is the almost catastrophic isolation from the labor market. We have a problem with the release of real professionals who really have all the skills that the job market requires from them right now.

A dual education system can address the gaps in the quality of education to market demands. At the same time, it is very important to introduce it at the level of higher education institutions, in order to enhance the highly qualified personnel and scientific potential of the country.

In Ukraine, dual education is still in the process of adopting a system implementation concept (September 19, 2018). And today we are observing the effective results of the experiment of introduction of dual education on the basis of the Higher Professional School of Kyiv (profession "Cook"), Higher Professional Art College of Lviv (profession "Painter"), Higher Professional College of Mechanical Engineering of Zaporizhzhia (profession "Turner").

The issue of three experimental groups showed positive results of introduction of dual education elements: high level of employment is up to $97 \%$, improvement of quality of vocational training by $12-17 \%$, additional financial income is up to 50 thousand UAH in each vocational educational institution, decrease costs for utilities and supplies, more sustainable and mutually beneficial cooperation with employers.

Thus, we can argue that education reform will bring effective results if economic, social and individual goals are achieved. The main task of the state is the purposeful management of the educational process and the correct formulation of requirements for it. Local governments should work towards developing a funding program for educational programs and educational institutions. In turn, the task of educational institutions is social responsibility for the quality of the educational process, and for the private sector - the formulation and updating of vocational training programs directly at enterprises.

Higher education is a key factor in the creation of knowledge-based societies. UNESCO is helping to develop data-driven policies that respond to new trends, and is seeking to make higher education more inclusive and innovative. The organization brings together, informs and guides the world community of higher education in issues such as mobility, recognition of qualifications, quality of education and inter-university cooperation. About which L. Hrynevych also stated in her report formulating the main purpose of reforming the higher education system (Hrynevych, 2018).

EU countries have succeeded in making European higher education a benchmark for quality education around the world, and today the development of the education sector is an integral part of EU cooperation with partner countries (European Association for Quality Assurance in Higher Education, 2015).

That is, within the framework of the European integration processes, Ukraine is obliged to review the current mechanisms of the educational pro- 
cess and to build a European curriculum. First of all, in order to unify the human capital within the country in the process of unification of economy and culture. And this is possible when building a quality education system that would meet the demands of the labor market.

The following actions can be taken by educational institutions to address the problem of youth unemployment improving the quality of education by:

- organizing internships at enterprises during or after the educational process;

- facilitating employment and adapting to the requirements of the labor market graduates of educational institutions by expanding the practice of contractual training system;

- introducing into the curricula self-determination and behavior in the labor market, job search technology and self-presentation;

- creating a database of successful graduates, a database of graduating consumer enterprises.

The main proposals for shaping the state's educational policy are:

- the systematization of work on the formation of generally accepted labor values in the early stages of personality formation (preschool educational institutions, school) introduction of educational standards for different levels of training in order to form the needs of work and creativity;

- to stimulate investment and innovation activities in order to improve jobs, character of work, increase its attractiveness for young people;

- reforming the vocational education system in the light of changing demand in the labor market;

- job quotas for graduates of educational institutions;

- tax incentives for those employers who create jobs for graduates or take them to work, give students the opportunity to go through a manufacturing practice;

- to expand the system of vocational guidance for youth and the unemployed.

At the same time, the implementation of the above measures is possible only in close cooperation between the state, educational institutions and employers.

\section{Conclusions and discussion}

Based on the results of the study of the modern state policy of managing the educational process and reforming the educational system of Ukraine, we have made the following conclusions:

1. The main problem of establishing basic educational institutions is now of a non-legal nature, but rather a public one. Thus, in shaping education policy, public opinion should be taken into account, and explanatory work 
should be taken to reduce the resistance of voluntary territorial integration. Thus, the decentralization process in the education sector, which still has a positive result, will be accelerated through synergy.

2. One of the major problems of Ukrainian higher education is the almost catastrophic detachment from the labor market. The implementation of the dual education system can be a tool for solving this problem. At the same time, it is very important to introduce it at the level of higher education institutions in order to enhance highly qualified personnel and scientific potential of the country.

3. The established policy of management of the educational process will bring effective results if economic, social and individual goals are achieved. In order to achieve effective results in improving the quality of education and reducing youth unemployment, the interaction of the state, educational institutions, local governments and the private sector is necessary.

Scientific novelty of the obtained results. In order to achieve effective results in improving the quality of education and reducing youth unemployment, the interaction of the state, educational institutions, local governments and the private sector is necessary.

The practical significance of the results obtained. The existing scientific and applied provisions on improving the quality of education and reducing youth unemployment can be applied by higher education institutions, state authorities and local self-government in the process of planning the socioeconomic development of both the country as a whole and the individual region.

Prospects for further scientific exploration in this direction. Prospects for further research in this area may be the development of a mechanism for reforming the national education system and the introduction of a dual education system.

\section{Acknowledgement}

This publication was made in accordance with the theme of the Research Institute of Kyiv National University of Culture and Arts within the theme: "Formation of modern paradigm of management of socio-cultural activity in the context of social development" (the Project \#0118U100544).

\section{References:}

Alton-Lee, A. (2006). Research and evidence in educational policy-making: New challenges. Wellington: Ministry of Education. Retrieved from www.minedu.govt/nz/goto/bestevidencesynthesis.

Baker, E. L., Gearhart, M., \& Herman, J. L. (1994). Evaluating the Apple Classrooms of Tomorrow (SM). Technology Assessment in Education and Training (E. L. Baker \& H. F. O'Neil, Eds.). Hillsdale, New Jersey: Erlbaum, 173-198. 
Bielova, L. O. (2018). Stan i problemy zdijsnennia upravlinnia iakistiu osvity ta osvitn'oi diial'nosti v Ukraini: ekspertne otsiniuvannia [Status and problems of quality management of education and educational activity in Ukraine: expert evaluation]. Teoriia ta praktyka derzhavnoho upravlinnia [Theory and practice of public administration], 2(61), 8-17 (in Ukr.).

Cabinet of Ministers of Ukraine (2013). Natsional'na stratehiia rozvytku osvity v Ukraini na period do 2021 roku [National Strategy for the Development of Education in Ukraine until 2021]. № 344/2013 Retrieved from https://zakon.rada.gov.ua/laws/show/344/2013 (in Ukr.).

Cabinet of Ministers of Ukraine (2015). Stratehiya staloho rozvytku "Ukraina 2020" [Sustainable Development Strategy "Ukraine 2020"]. № 5/2015. Retrieved from https://zakon.rada.gov.ua/laws/show/5/2015 (in Ukr.).

Ekonomichnyi dyskusiinyi klub (2017). Pozytsiia Ukrainy v rejtynhu krain svitu za indeksom hlobal'noi konkurentospromozhnosti 2017-2018 [Ukraine's position in the world ranking according to the Global Competitiveness Index 2017-2018]. Retrieved from http://edclub.com.ua/analityka/pozyciyaukrayiny-v-reytyngu-krayin-svitu-za-indeksom-globalnoyi-konkurentospromo zhnosti-2 (in Ukr.).

European Association for Quality Assurance in Higher Education (ENQA) (2015). Standards and Guidelines for Quality Asssurance in the European Higher Education Area (ESG). Brussels, Belgium. Retrieved from https:// enqa.eu/wp-content/uploads/2015/11/ESG_2015.pdf.

Hrushyna, A. I. (2018). Formuvannia systemy stratehichnoho upravlinnia v haluzi kul'tury [Formation of the system of strategic management in the field of culture]. Visnyk Kyyivskoho natsionalnoho universytetu kultury $i$ mystetstv. Seriya: Menedzhment sotsiokulturnoyi diyalnosti [Bulletin of Kiev National University of Culture and Arts. Series in Management of Social and Cultural Activity], 2, 107-119, doi: 10.31866/2616-7573.2. 2018.149470 (in Ukr.).

Hrynevych, L. M. (2018). Zupynyty vidtik molodi mozhna lyshe iakistiu osvity [Only the quality of education can stop the outflow of young people]. Retrieved from https://osvita.ua/vnz/59118/ (in Ukr.).

Iarychev, M. U. (2016). Molodezh kak strategicheskii resurs gosudarstva [Young people as a strategic resource of the state]. Molodoi uchenyi [Young scientist], 2, 1008-1011 (in Russ.).

Kremin' V., Levovyts'kyj T., Ohnev'iuk V., \& Sysoieva S. (2013). Osvitni reformy: misiia, dijsnist', refleksiia [Educational reforms: mission, reality, reflection]. Kyiv: Edel'vejs (in Ukr.).

Kucherenko, S. Yu. (2018). Suchasnyj stan, tendentsii ta problemy rozvytku osvity v Ukraini [Current state, trends and problems of education development in Ukraine]. Ekonomichnyj visnyk universytetu [Economic Herald of the University], 36(1), 51-59, doi: 10.5281/zenodo.1219827 (in Ukr.).

Martynyshyn, Ya. M., Khlystun, O. S., Kovalenko, Ye. Ya., Hrushyna, A. I., \& Tadlia, O. M. (2017). Obgruntuvannia paradyhmy menedzhment-osvity u sotsiokul'turnij sferi [Substantiation of the paradigm of management 
education in the socio-cultural sphere] (Ya. M. Martynyshyn, Ed.). Bila Tserkva: Vydavets O. V. Pshonkivskyj (in Ukr.).

Maslov, V. I., Bondar, O. S., \& Horash, K. V. (2012). Naukovi osnovy ta tekhnolohii kompetentnoho upravlinnia zahal'noosvitnimy navchal'nymy zakladamy [Scientific fundamentals and technologies of competent management of general educational institutions]. Ternopil': Krok (in Ukr.).

Meleshko, V. V. (2018). Problemy upravlinnia opornymy zakladamy zahal'noi seredn'oi osvity v umovakh detsentralizatsii [Problems of management of secondary education institutions in the conditions of decentralization]. Ukrains'kyj pedahohichnyj zhurnal [Ukrainian Pedagogical Journal], 2, 27-33 (in Ukr.).

Ministry of Education and Science of Ukraine (2014). Stratehiia reformuvannia vyschoi osvity $v$ Ukraini do 2020 roku [The strategy of reforming higher education in Ukraine until 2020]. Retrieved from http://tnpu.edu.ua/ EKTS/strate2014.pdf (in Ukr.).

Petrilli, M. J. (2018). Where Education Reform Goes from Here. Retrieved from https://www.educationnext.org/where-education-reform-goes-here/.

Shtyfurko, T. (2018). Vidtik mizkiv za kordon: scho mozhe zrobyty Ukraina, poky ne pizno [The brain drain abroad: what Ukraine can do, it is not too late]. Retrieved from https://zik.ua/news/2018/05/21/vidtik_mizkiv_za_ kordon_shcho_mozhe_zrobyty_ukraina_poky_ne_pizno_1328437 (in Ukr.).

State Statistics Service of Ukraine (2019). Demohrafichna ta sotsialna statystyka. Osvita [Demographic and social statistics. Education]. Retrieved from http://www.ukrstat.gov.ua/ (in Ukr.).

Tytarenko, L. M., \& Maliuha, S. V. (2014). Molodizhnyj sehment rynku pratsi v systemi natsional'noi ekonomiky [Youth segment of the labor market in the system of the national economy]. Ekonomika $i$ rehion [Economy and region], 5(48), 34-40. Retrieved from http://nbuv.gov.ua/ UJRN/econrig_2014_5_8(in Ukr.).

UNDP Ukraine (2017). Stratehiia staloho rozvytku Ukrainy do 2030 roku [Strategy of Ukraine's Sustainable Development till 2030]. Retrieved from http://www.ua.undp.org/content/dam/ukraine/docs/SDGreports/ UNDP_Strategy_v06-optimized.pdf (in Ukr.).

UNDP Ukraine (2018). Indeks liuds'koho rozvytku: Ukraina posila 88 pozytsiiu sered 189 krain [Human Development Index: Ukraine ranked 88th among 189 countries]. Retrieved from http://www.ua.undp.org/content/ukraine/ uk/home/learnmore.html?tagid=topics\%3Ahdr (in Ukr.).

World Economic Forum (2017). The Global Human Capital Report 2017. Retrieved from https://www.weforum.org/reports/the-global-humancapital-report-2017.

World Economic Forum (2018). The Global Competitiveness Report 2018. Retrieved from https://www.weforum.org/reports/the-global-competit veness-report-2018.

Zhabin, S., \& Kaz'mina, O. (2017). Molodi naukovtsi: sotsial'nyj stan ta umovy pratsi v Natsional'nij akademii nauk Ukrainy [Young scientists: social status and working conditions at the National Academy of Sciences of Ukraine]. Spil'ne [Commons]. Retrieved from https://commons.com. ua/uk/molodi-naukovci-ukrayini/ (in Ukr.). 